\title{
Positive physical and mental outcomes for residents in nursing facilities using music: a systematic review
}

\author{
Michael Mileski' \\ Matthew Brooks' \\ Alison Kirsch' \\ Fengmei Lee ${ }^{2}$ \\ Amanda LeVieux' \\ Alexandra Ruiz ${ }^{3}$ \\ 'School of Health Administration, \\ Texas State University, San Marcos, \\ TX 78666, USA; '2Department \\ of Sociology, Long Term Care \\ Administration, Texas State University, \\ San Marcos, TX 78666, USA; ${ }^{3}$ School \\ of Social Work, Texas State University, \\ San Marcos, TX 78666, USA
}

This article was published in the following Dove Medical Press journal: Clinical Interventions in Aging

\begin{abstract}
Objectives: The objective of this study was to investigate the applicability and effectiveness of the use of music in providing for positive physical and mental outcomes in nursing facilities. Problem: Lack of quality of life (QOL) has been a significant issue within nursing facilities. With the rise in census due to Baby Boomers, it has become imperative to find ways to increase overall QOL.
\end{abstract}

Methods: The research team participants conducted a literature review via Cumulative Index of Nursing and Allied Health Literature, PubMed (MEDLINE), and Academic Search Ultimate to collect data regarding the use of music to provide for positive physical and mental outcomes in nursing facilities.

Results: The most common facilitator mentioned was increased socialization or communication (18\%), followed by reduced depression (12\%), improved physical health (11\%), and reduced agitation or behavior problems $(9 \%)$. The most common barriers were as follows: cannot isolate effects of music (26\%), cost prohibitive (11\%), difficult to implement (11\%), and no significant improvements in QOL or well-being (11\%).

Conclusion: The use of music showed positive outcomes for residents in nursing facilities and should be considered for implementation as part of the normal culture within such facilities.

Keywords: music, music therapy, nursing facilities, skilled nursing, outcomes

\section{Introduction}

By the year 2030, one of every five residents in the USA will be above the age of 65 years. ${ }^{1}$ For the first time in history, there will be more people over the age of 65 years than under the age of 18 years residing in the USA. It is currently estimated 4.74 million people utilize home health care agencies, 1.4 million reside in nursing facilities, 1.24 million utilize hospice, 713,000 live in residential care communities, and 273,000 utilize adult day service centers that help serve the growing population. ${ }^{2}$ The number of individuals projected to require use of long-term care services is projected to increase to roughly 27 million by the year $2050 .{ }^{3}$ Because of the rapidly growing elderly population, health care agencies and government health organizations have been anticipating ways to meet the upcoming need. The focus by long-term care providers has shifted to finding easier ways to give a higher quality of care overall.

\section{Background}

School of Health Administration, Texas

State University, 60I University Drive,

San Marcos, TX 78666, USA

$\mathrm{Tel}+$ I 8327524419

Email mileski@txstate.edu
The effects of music for the promotion of health have been explored throughout history. From the ancient cultures in Asia, Egypt, Romania, Africa, and America, music was utilized to improve spirits, ward off diseases, and provide an overall calming effect on 
people. ${ }^{4}$ Music has become a valuable resource when working with the elderly in nursing facilities and has been utilized for many years to reduce agitation, stress, and depression. ${ }^{4,5}$ When thinking in terms of body, mind, and spirit as being interconnected, music is a method of connection that touches every aspect of our being and can have positive effects on the quality of life (QOL) as we age..$^{5}$ Music and music therapy have been proven to work in psychiatric hospitals, drug and alcohol programs, correctional facilities, rehabilitation facilities, acute care hospitals, as well as hospice services and nursing facilities. ${ }^{5}$

\section{Significance}

Studies on the positive effects of music in palliative or hospice care have been documented well, ${ }^{6,7}$ but more specific research has been done to analyze the effects of music on the elderly within nursing facility setting. As the morbidity rate decreases and the elderly population increases, there is a need to find ways to improve the QOL for the elderly, especially for the oldest-old (over age 85) who have the increased probability of showing signs of depression, dementia, and other health issues. ${ }^{8}$

There are $\sim 92 \%$ of elderly adults who have at least one chronic illness and $\sim 77 \%$ have at least two or more health issues. ${ }^{9}$ Chronic illnesses reduce the ability of a person to perform normal activities, which is a major contributor to depression. ${ }^{6,8}$ Due to the need to administer medications for these ailments, to add another pharmacological remedy for depression or anxiety can cause adverse side effects and unwanted drug interactions. ${ }^{9}$ The Centers for Disease Control and Prevention in 2007-2008 provided statistics that $76 \%$ of the elderly were taking two medications and $37 \%$ of them were taking more than five medications. ${ }^{9}$ Music and music therapy can positively reduce the need for additional medications and have positive effects on the elderly if conducted in the proper manner., ${ }^{4,6,8-11}$

If nursing staff and family caregivers understand the effectiveness of music therapy with increasing the QOL for the elderly and how it is best applied, low-cost and nonpharmaceutical measures can be taken to make positive changes. ${ }^{6,9,10}$ As resident behaviors are time consuming and stressful for staff and residents, the need exists to continue research in this area to show methods to measure the impact of music and music therapy in the care of the elderly. ${ }^{10}$ In addition, there is evidence to suggest that the use of music in a nursing facility environment can prevent depression, which would be an asset for use in resident care. ${ }^{11}$ Music and/or music therapy can be a low-cost and effective intervention to improve physical health and psychological well-being.

\section{Materials and methods} Design

For this study, the authors conducted a systematic review of peer-reviewed articles that were found across three databases. The PRISMA guidelines were utilized to ensure a consistent and exact reporting of the results. The search began on June 16, 2018 and it was completed on July 1, 2018. The databases utilized were Cumulative Index of Nursing and Allied Health Literature (CINAHL), PubMed (MEDLINE), and Academic Search Ultimate.

The Medical Subject Headings at the National Center for Biotechnology Information were used to discover initial keywords. However, the initial search terms did not generate enough germane studies on the topic of interest and it was expanded to include other key words that could be applied to nursing facilities, music therapy, and QOL or measures of well-being. After carefully examining the literature and the key terms for the search scope, the keywords that were used were placed in the complex, three-string Boolean search that is displayed in Figure 1. Duplicates from each of the databases were removed and a final search to add other relevant articles found in the citations that met the inclusion criteria was conducted.

\section{Inclusion criteria}

The authors reviewed the articles individually to determine which articles were germane and then summarized the themes. Authors then agreed upon inclusion of the final sample of articles to be included in this study. Criteria for inclusion were articles that were published in the English language, peer-reviewed articles, and had only human subjects. In addition, the articles needed to have been published by academic journals between January 1, 2013 and July 1, 2018. Articles were included if they examined the effects of music or music therapy on physical or mental health for residents in some type of geriatric living environment.

\section{Exclusion criteria}

Articles were included only if they were determined to be germane by all authors. Literature reviews, study protocols, meta-analyses, trade industry reports, and poster presentations were excluded from the search. If an article did not display a clear, scientific format, it was also excluded from the results. Articles that did not reference music as a main research component were excluded. Bias was not a factor in selecting articles for this study. After examining all the articles as a group and coming to a consensus on germane articles, the final number of articles to be included in this 


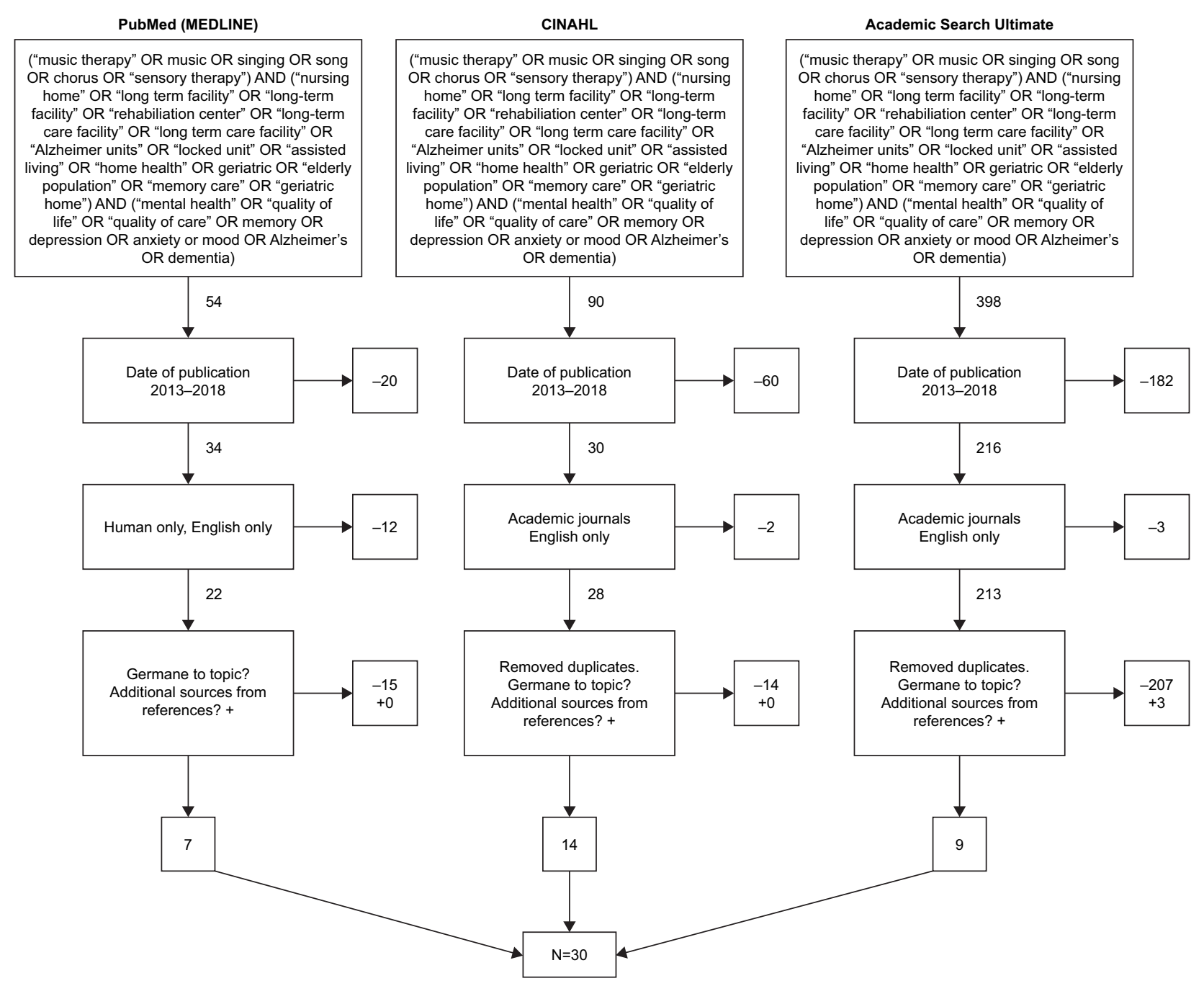

Figure I PRISMA diagram.

review was 30. This final sample was then analyzed by all authors for consensus which was achieved. This yielded a kappa statistic $(\kappa=1)$, showing strong reliability.

\section{Data analysis}

Brief narrative summaries related to the impact of music on physical and mental health factors were extracted from each of the articles. The authors then identified facilitators and barriers to the effectiveness of the music or music therapy. General observations were also noted, and all the information was compiled into a literature matrix (Table 1). These facilitators and barriers were then grouped into larger themes within each category; the themes were chosen together and with consensus of all the authors. Two affinity matrix tables (Tables 3 and 4) were then created for the facilitators and barriers. Each table shows the themes, how often they occurred in the articles, their frequency sum, and the frequency percentage.

\section{Results Study selection}

The process of selecting articles is shown in the PRISMA diagram in Figure 1. The initial search yielded a total of 542 articles from the CINAHL, PubMed (MEDLINE), and Academic Search Ultimate databases. There were 515 articles excluded because they did not meet a set of inclusion criteria, which left 27 germane articles. Looking through the citations for other relevant articles, three additional articles were added. A total of 30 articles were then used for the analysis.

The studies being considered in this systematic review were conducted in hospice settings, in aging communities, and in nursing facilities. It includes 14,104 participants of which $<0.1 \%$ were $<60$ years old. The studies included both male and female sexes from 10 different countries. Studies were conducted with patients with low to medium cognition 
Table I Studies selected for review and a summary of design, methods, and results

\begin{tabular}{|c|c|c|c|c|c|}
\hline $\begin{array}{l}\text { Author/date/ } \\
\text { location }\end{array}$ & Aim & Sample/settings & Methods & Assessment tool & Key findings \\
\hline $\begin{array}{l}\text { Altan Sarikaya and } \\
\text { Oguz }{ }^{12} / 2016 / \text { Turkey }\end{array}$ & $\begin{array}{l}\text { Determine the } \\
\text { quality of sleep and } \\
\text { the effect of passive } \\
\text { music therapy given } \\
\text { at bedtime on sleep } \\
\text { quality }\end{array}$ & $\begin{array}{l}31 \text { people aged 34-9I } \\
\text { years excluding those } \\
\text { with severe hearing } \\
\text { impairment and memory } \\
\text { problems }\end{array}$ & $\begin{array}{l}\text { Quasi- } \\
\text { experimental }\end{array}$ & $\begin{array}{l}\text { Questionnaires; } \\
\text { Pittsburgh Sleep Quality } \\
\text { Index; pre-test and post- } \\
\text { intervention test }\end{array}$ & $\begin{array}{l}\text { The study found that } \\
\text { passive music therapy } \\
\text { given at bedtime to } \\
\text { elderly subjects has } \\
\text { positive effects on the } \\
\text { quality of sleep }\end{array}$ \\
\hline $\begin{array}{l}\text { Cheung et al }{ }^{13 /} \\
\text { November 2016/ } \\
\text { China }\end{array}$ & $\begin{array}{l}\text { To examine the } \\
\text { effects of the 6-week } \\
\text { MM intervention, } \\
\text { as compared with } \\
\text { music listening and } \\
\text { social activity, on the } \\
\text { cognitive functions } \\
\text { of people with } \\
\text { moderate dementia }\end{array}$ & $\begin{array}{l}\text { I } 65 \text { nursing home } \\
\text { residents with moderate } \\
\text { dementia }\end{array}$ & $\begin{array}{l}\text { Multi-centered } \\
\text { randomized } \\
\text { controlled trial }\end{array}$ & $\begin{array}{l}\text { Pre-test and post- } \\
\text { intervention test }\end{array}$ & $\begin{array}{l}\text { The finding reveals that } \\
\text { the MM intervention } \\
\text { may be useful for } \\
\text { enhancing the cognitive } \\
\text { function of people with } \\
\text { dementia }\end{array}$ \\
\hline $\begin{array}{l}\text { Clements-Cortes }{ }^{14} / \\
\text { December 2014/ } \\
\text { Canada }\end{array}$ & $\begin{array}{l}\text { To study three } \\
\text { of Hettler's six } \\
\text { dimensions of } \\
\text { wellness: physical, } \\
\text { emotional, and } \\
\text { social health while } \\
\text { participating in choir } \\
\text { sessions }\end{array}$ & $\begin{array}{l}\text { I } 6 \text { participants in a large } \\
\text { metropolitan long-term } \\
\text { care facility }\end{array}$ & Mixed-methods & $\begin{array}{l}\text { Pre-test and post- } \\
\text { intervention test; } \\
\text { interviews; Likert scales }\end{array}$ & $\begin{array}{l}\text { Finding indicate } \\
\text { that singing in a } \\
\text { choir facilitated by a } \\
\text { music therapist and } \\
\text { accompanist was a } \\
\text { beneficial intervention } \\
\text { for improving moss, } \\
\text { happiness and energy } \\
\text { for decreasing pain } \\
\text { and anxiety over the } \\
\text { entire } 16 \text { weeks both } \\
\text { for cognitively intact } \\
\text { older adults and those } \\
\text { diagnosed with a } \\
\text { cognitive impairment }\end{array}$ \\
\hline $\begin{array}{l}\text { Davidson et al }{ }^{15} / \text { June } \\
20 \mid 4 / \text { Australia }\end{array}$ & $\begin{array}{l}\text { To evaluate the effect } \\
\text { of singing program } \\
\text { developed specifically } \\
\text { for older community- } \\
\text { dwelling people on } \\
\text { measures of health } \\
\text { and well-being }\end{array}$ & $\begin{array}{l}36 \text { people recruited } \\
\text { into the intervention } \\
\text { and } 29 \text { completed from } \\
\text { Silver Chain, a large } \\
\text { health and aged care } \\
\text { service provider in } \\
\text { western Australia and } \\
\text { the readership of a local } \\
\text { community newspaper }\end{array}$ & Mixed-methods & $\begin{array}{l}\text { Pre-test and post- } \\
\text { intervention test; } \\
\text { post-intervention semi- } \\
\text { structured interviews }\end{array}$ & $\begin{array}{l}\text { Well-structured } \\
\text { community-based } \\
\text { singing programs have } \\
\text { the potential to impact } \\
\text { positively upon the } \\
\text { well-being of older } \\
\text { people, program viability } \\
\text { depends on support } \\
\text { with recruitment, } \\
\text { transport, and funding }\end{array}$ \\
\hline $\begin{array}{l}\text { Davison et al }{ }^{16 / 2016 /} \\
\text { Australia }\end{array}$ & $\begin{array}{l}\text { To search for an } \\
\text { intervention that } \\
\text { would prove so } \\
\text { engrossing that } \\
\text { agitated behaviors } \\
\text { were reduced both } \\
\text { in frequency and } \\
\text { severity; would } \\
\text { address high levels } \\
\text { of depressive and } \\
\text { anxious symptoms } \\
\text { exhibited by people } \\
\text { with dementia and } \\
\text { could be personalized }\end{array}$ & $\begin{array}{l}\text { I } 6 \text { residents from } 2 \\
\text { nursing homes entered } \\
\text { study, II completed the } \\
\text { protocol, ages ranging } \\
\text { from } 76 \text { to } 95 \text { years with } \\
\text { dementia }\end{array}$ & $\begin{array}{l}\text { Single-blinded, } \\
\text { cross-over } \\
\text { design }\end{array}$ & $\begin{array}{l}\text { Cornell Scale for } \\
\text { Depression in Dementia; } \\
\text { Rating for Anxiety in } \\
\text { Dementia scale; MMSE; } \\
\text { Clinical Dementia Rating } \\
\text { scale, staff-interviews }\end{array}$ & $\begin{array}{l}\text { The findings reported } \\
\text { by participating } \\
\text { residents, their relatives, } \\
\text { and nursing home } \\
\text { staff members were } \\
\text { overwhelmingly positive, } \\
\text { and the majority would } \\
\text { recommend intervention } \\
\text { for other residents with } \\
\text { dementia }\end{array}$ \\
\hline
\end{tabular}

(Continued) 
Table I (Continued)

\begin{tabular}{|c|c|c|c|c|c|}
\hline & Aim & Sample/settings & Methods & Assessment tool & Key findings \\
\hline & $\begin{array}{l}\text { by family members } \\
\text { and required minimal } \\
\text { support, even for } \\
\text { residents with } \\
\text { moderate degrees of } \\
\text { dementia }\end{array}$ & & & & \\
\hline $\begin{array}{l}\text { Edwards }{ }^{17} / \text { May } \\
2015 / \text { Europe }\end{array}$ & $\begin{array}{l}\text { Relates how Music } \\
\text { Mirrors, simple } \\
\text { digital resources can } \\
\text { be used to help and } \\
\text { stimulate those with } \\
\text { dementia, whether } \\
\text { by encouraging } \\
\text { engagement or by } \\
\text { sparking personal } \\
\text { memories }\end{array}$ & $\begin{array}{l}\text { I male with history } \\
\text { of a stroke that left } \\
\text { him with severe brain } \\
\text { damage }\end{array}$ & Retrospective & Music Mirrors & $\begin{array}{l}\text { Music Mirrors is an } \\
\text { intervention as a simple } \\
\text { way to record signs } \\
\text { of our lives so that } \\
\text { other can find us later } \\
\text { and help to keep our } \\
\text { memories and feelings } \\
\text { alive }\end{array}$ \\
\hline $\begin{array}{l}\text { Eggert et al }{ }^{18} / 2015 / \\
\text { USA }\end{array}$ & $\begin{array}{l}\text { Explore how } \\
\text { exposure to } \\
\text { preferred music } \\
\text { and nature images } \\
\text { affect engagement, } \\
\text { cognitive ability, and } \\
\text { dementia-related } \\
\text { disorder behavior } \\
\text { such as agitation } \\
\text { for those diagnosed } \\
\text { with AD and other } \\
\text { dementias }\end{array}$ & $\begin{array}{l}300 \text { residents including } \\
\text { a maximum of } 48 \\
\text { individuals in assisted } \\
\text { living, } 24 \text { in Memory } \\
\text { Care, and } 44 \text { receiving } \\
\text { short-term rehabilitation } \\
\text { and long-term care }\end{array}$ & $\begin{array}{l}\text { Quasi- } \\
\text { experimental, } \\
\text { nonrandomized } \\
\text { controlled, } \\
\text { interrupted time } \\
\text { series }\end{array}$ & $\begin{array}{l}\text { Cohen-Mansfield } \\
\text { Agitation Inventory; } \\
\text { Individualized Dementia } \\
\text { Engagement and } \\
\text { Activities Scale; Montreal } \\
\text { cognitive Assessment; } \\
\text { MMSE; pre-test and post- } \\
\text { intervention test }\end{array}$ & $\begin{array}{l}\text { Music and nature images } \\
\text { are effective positive } \\
\text { distractions for reducing } \\
\text { anxiety or stress using } \\
\text { environmental features } \\
\text { or conditions as mature } \\
\text { images have proven to } \\
\text { be effective in reducing } \\
\text { stress in health care } \\
\text { settings and controlled } \\
\text { laboratory setting plus } \\
\text { the use of preferred } \\
\text { music has shown to be } \\
\text { effective in reducing } \\
\text { agitation and improving } \\
\text { mood during bathing }\end{array}$ \\
\hline $\begin{array}{l}\text { Fu et al }{ }^{4} / \text { February } \\
2018 / \text { USA }\end{array}$ & $\begin{array}{l}\text { Assess the feasibility, } \\
\text { acceptability, and } \\
\text { impact of a I2-week } \\
\text { group singing } \\
\text { program on cognitive } \\
\text { function, lung health, } \\
\text { and QOL }\end{array}$ & $\begin{array}{l}49 \text { participants from } \\
3 \text { senior communities } \\
\text { aged }>60 \text { years, no } \\
\text { self-reported dementia } \\
\text { diagnosis }\end{array}$ & $\begin{array}{l}\text { Quasi- } \\
\text { experimental }\end{array}$ & $\begin{array}{l}\text { Pre- and post-test } \\
\text { surveys, pulse oximeter } \\
\text { to measure } \mathrm{O}_{2} \text { saturation }\end{array}$ & $\begin{array}{l}\text { Group singing may } \\
\text { promote memory, } \\
\text { language, speech } \\
\text { information processing, } \\
\text { executive function, and } \\
\text { respiratory strength }\end{array}$ \\
\hline $\begin{array}{l}\text { Gill and Englert } \\
\text { October } 2013 / \text { USA }\end{array}$ & $\begin{array}{l}\text { Test the hypothesis } \\
\text { that music will } \\
\text { reduce falls in } \\
\text { institutionalized } \\
\text { persons with } \\
\text { dementia }\end{array}$ & $\begin{array}{l}55 \text { participants aged } \\
65-90 \text { years in a } \\
\text { dementia unit over } \\
\text { 4-month time frame; } \\
\text { all participants have } \\
\text { some form of dementia }\end{array}$ & $\begin{array}{l}\text { Quasi- } \\
\text { experimental, } \\
\text { I-group time- } \\
\text { series }\end{array}$ & Medical records & $\begin{array}{l}\text { No significant difference } \\
\text { in fall reduction }\end{array}$ \\
\hline $\begin{array}{l}\text { Gök Ugur et } \mathrm{al}^{20} / \mathrm{July} \\
\text { 20I7/Turkey }\end{array}$ & $\begin{array}{l}\text { Determine the effect } \\
\text { of music therapy } \\
\text { on depression } \\
\text { and physiological } \\
\text { parameters in elderly } \\
\text { people living in a } \\
\text { Turkish nursing } \\
\text { home over 8-week } \\
\text { time frame }\end{array}$ & $\begin{array}{l}64 \text { elderly people } \\
\text { currently residing in a } \\
\text { nursing home }\end{array}$ & $\begin{array}{l}\text { Randomized } \\
\text { controlled trial, } \\
\text { single-blind }\end{array}$ & $\begin{array}{l}\text { Pre- and post-test data, } \\
\text { GDS, and physiological } \\
\text { parameters measuring BP } \\
\text { and HR }\end{array}$ & $\begin{array}{l}\text { Music therapy decreased } \\
\text { the depression level and } \\
\text { blood pressure }\end{array}$ \\
\hline
\end{tabular}


Table I (Continued)

\begin{tabular}{|c|c|c|c|c|c|}
\hline $\begin{array}{l}\text { Author/date/ } \\
\text { location }\end{array}$ & Aim & Sample/settings & Methods & Assessment tool & Key findings \\
\hline $\begin{array}{l}\text { Hamilton et al22/May } \\
2013 / \text { USA }\end{array}$ & $\begin{array}{l}\text { Explore how } \\
\text { religious songs were } \\
\text { used to cope with } \\
\text { stressful life events } \\
\text { and to explore the } \\
\text { religious beliefs } \\
\text { associated with these } \\
\text { songs }\end{array}$ & $\begin{array}{l}65 \text { African American } \\
\text { men and women } \\
\text { aged } \geq 50 \text { years }\end{array}$ & Cross-sectional & $\begin{array}{l}\text { Survey and interview } \\
\text { results }\end{array}$ & $\begin{array}{l}\text { Religious songs } \\
\text { improved mental health, } \\
\text { QOL, and socialization }\end{array}$ \\
\hline $\begin{array}{l}\text { Johnson et } \mathrm{al}^{23} / \text { April } \\
2013 / \text { Finland }\end{array}$ & $\begin{array}{l}\text { Examine the } \\
\text { relationship between } \\
\text { perceived benefits } \\
\text { associated with } \\
\text { choral singing } \\
\text { and QOL among } \\
\text { community-dwelling } \\
\text { older adults }\end{array}$ & $\begin{array}{l}\text { I I } 7 \text { adults } \\
\text { aged } \geq 65 \text { years }\end{array}$ & Cross-sectional & $\begin{array}{l}\text { WHOQOL-BREF } \\
\text { questionnaire }\end{array}$ & $\begin{array}{l}\text { Choral singers reported } \\
\text { few symptoms of } \\
\text { depression and high } \\
\text { overall QOL and health } \\
\text { satisfaction }\end{array}$ \\
\hline $\begin{array}{l}\text { Kerer et } \mathrm{al}^{24 /} \\
\text { December 2013/ } \\
\text { Austria }\end{array}$ & $\begin{array}{l}\text { Test and analyze } \\
\text { explicit memory } \\
\text { of participants to } \\
\text { music in different } \\
\text { stages of early } \\
\text { dementia in terms } \\
\text { of identification } \\
\text { of familiar music } \\
\text { excerpts }\end{array}$ & $\begin{array}{l}43 \text { participants } \\
\text { aged } \geq 60 \text { years, } \\
23 \text { participants had } \\
\text { AD or mild cognitive } \\
\text { impairment }\end{array}$ & $\begin{array}{l}\text { Interrupted time } \\
\text { series, quasi- } \\
\text { experimental }\end{array}$ & $\begin{array}{l}\text { Mini mental state } \\
\text { examination, verbal and } \\
\text { figural memory test }\end{array}$ & $\begin{array}{l}\text { Mild cognitive } \\
\text { impairment and patients } \\
\text { with } A D \text { showed } \\
\text { significantly poorer } \\
\text { performances in tasks } \\
\text { requiring verbal memory } \\
\text { of musical excerpts than } \\
\text { healthy participants }\end{array}$ \\
\hline $\begin{array}{l}\text { Kirkland et } \mathrm{al}^{25} / \\
\text { January 2015/ } \\
\text { Canada }\end{array}$ & $\begin{array}{l}\text { Analyze the } \\
\text { outcomes of a } \\
\text { co-led combined } \\
\text { spiritual care and } \\
\text { music therapy. } \\
\text { Also, to identify } \\
\text { useful intervention } \\
\text { strategies by } \\
\text { defining meaning and } \\
\text { significance of the } \\
\text { group }\end{array}$ & $\begin{array}{l}\text { I } 2 \text { long-term care } \\
\text { residents aged 52-99 } \\
\text { years }\end{array}$ & Mixed methods & $\begin{array}{l}\text { Dementia care mapping, } \\
\text { observation, videotaping, } \\
\text { and interviews }\end{array}$ & $\begin{array}{l}\text { Residents' experiences } \\
\text { increased social } \\
\text { involvement, identify, } \\
\text { attachment, and a } \\
\text { connectedness to their } \\
\text { spiritual beliefs }\end{array}$ \\
\hline $\begin{array}{l}\text { Lancioni et al }{ }^{26 /} \\
\text { February } 2013 / \text { taly }\end{array}$ & $\begin{array}{l}\text { Assess the impact on } \\
\text { the social capabilities } \\
\text { of patients with } \\
\text { AD with active, } \\
\text { compared to passive } \\
\text { music conditions }\end{array}$ & $\begin{array}{l}10 \text { patients with } \\
\text { moderate to high stages } \\
\text { of Alzheimer's, aged } \\
78-84 \text { years }\end{array}$ & $\begin{array}{l}\text { Interrupted time } \\
\text { series }\end{array}$ & $\begin{array}{l}\text { MMSE, observations, } \\
\text { Hamilton Rating Scale, } \\
\text { and the GDS }\end{array}$ & $\begin{array}{l}\text { An active music } \\
\text { stimulation can be an } \\
\text { effective and socially } \\
\text { preferable way to obtain } \\
\text { positive participation } \\
\text { from patients with AD, } \\
\text { but they were not able } \\
\text { to activate the music on } \\
\text { their own }\end{array}$ \\
\hline $\begin{array}{l}\text { Liao et } \mathrm{al}^{27} / \text { February } \\
2018 / \text { China }\end{array}$ & $\begin{array}{l}\text { Determine if the } \\
\text { combination of } \\
\text { music and Tai Chi } \\
\text { (motion) would have } \\
\text { a positive effect on } \\
\text { elderly persons with } \\
\text { depression }\end{array}$ & $\begin{array}{l}\text { I07 participants } \\
\text { with GDS scores of } \\
\text { II-25 years, aged } \\
>60 \text { years, residing } \\
\text { in community for } \\
\text { I year, and adequately } \\
\text { alert to complete } \\
\text { intervention }\end{array}$ & $\begin{array}{l}\text { Two-armed } \\
\text { randomized } \\
\text { controlled, cross } \\
\text { sectional }\end{array}$ & $\begin{array}{l}\text { Split-Plot ANOVA used } \\
\text { to identify changes in } \\
\text { depression }\end{array}$ & $\begin{array}{l}\text { Use of Tai Chi in } \\
\text { combination with music } \\
\text { therapy significantly } \\
\text { lowered depression } \\
\text { scores and is a viable } \\
\text { non-pharmacological } \\
\text { intervention }\end{array}$ \\
\hline
\end{tabular}

(Continued) 
Table I (Continued)

\begin{tabular}{|c|c|c|c|c|c|}
\hline $\begin{array}{l}\text { Author/date/ } \\
\text { location }\end{array}$ & Aim & Sample/settings & Methods & Assessment tool & Key findings \\
\hline Liu et $\mathrm{al}^{28} / 20 \mathrm{I} / \mathrm{USA}$ & $\begin{array}{l}\text { Compare music } \\
\text { therapy referral } \\
\text { reasons and delivery } \\
\text { for hospice patients } \\
\text { living in skilled } \\
\text { nursing facilities } \\
\text { compared to home }\end{array}$ & $\begin{array}{l}2,930 \text { patients living in } \\
\text { nursing homes and I,837 } \\
\text { living at home who were } \\
\text { seeking hospice services }\end{array}$ & Retrospective & Medical records & $\begin{array}{l}\text { The referral reasons } \\
\text { for music therapy were } \\
\text { different based on the } \\
\text { location of care and } \\
\text { diagnosis and individual } \\
\text { care plans need to be } \\
\text { created }\end{array}$ \\
\hline $\begin{array}{l}\text { Matto et } \mathrm{al}^{29} / 2015 / \\
\text { USA }\end{array}$ & $\begin{array}{l}\text { Evaluate the results } \\
\text { from music, imagery, } \\
\text { and movement when } \\
\text { introduced into a } \\
\text { long-term facility } \\
\text { for persons with } \\
\text { impaired cognition } \\
\text { and depression }\end{array}$ & $\begin{array}{l}\text { Two groups of } 10 \\
\text { participants each with } \\
\text { MMSE with cognitive } \\
\text { scores between } 17 \text { and } \\
30 \text { and with depression } \\
\text { based on the (GDS over } \\
3 \text { months) }\end{array}$ & $\begin{array}{l}\text { Two-armed } \\
\text { randomized } \\
\text { controlled }\end{array}$ & $\begin{array}{l}\text { MMSE, Mini-Cog, } \\
\text { which is used to assess } \\
\text { cognition and the } \\
\text { Generic Depressive Scale }\end{array}$ & $\begin{array}{l}\text { Introducing music, } \\
\text { imagery, visual } \\
\text { expression, and } \\
\text { movement increased } \\
\text { cognition scores, and } \\
\text { significantly lowered } \\
\text { depression scores }\end{array}$ \\
\hline $\begin{array}{l}\text { Melhuish et } \mathrm{al}^{30} / \\
2017 / \mathrm{UK}\end{array}$ & $\begin{array}{l}\text { Evaluate the attitudes } \\
\text { and perceptions of } \\
\text { staff who participated } \\
\text { in music therapy and } \\
\text { dance movement } \\
\text { therapy with } \\
\text { dementia patients in } \\
\text { a nursing home }\end{array}$ & $\begin{array}{l}8 \text { of } 34 \text { staff members } \\
\text { were chosen for the } \\
\text { study. } 12 \text { men and } \\
\text { I } 8 \text { women with an } \\
\text { average age of } 76 \text { years } \\
\text { and diagnosed with } \\
\text { dementia in } 90 \% \text { of cases }\end{array}$ & $\begin{array}{l}\text { Two-armed } \\
\text { randomized } \\
\text { controlled }\end{array}$ & $\begin{array}{l}\text { In-depth interviews } \\
\text { were conducted } \\
\text { with } 7 \text { of the } 8 \text { staff } \\
\text { members. Interpretive } \\
\text { phenomenological } \\
\text { analysis was used to } \\
\text { analyze the data }\end{array}$ & $\begin{array}{l}\text { Both interventions, } \\
\text { music therapy and dance } \\
\text { movement therapy, had } \\
\text { a parallel positive effect } \\
\text { in the way the staff } \\
\text { were able to discover } \\
\text { the skills and feelings of } \\
\text { the participants and had } \\
\text { a positive influence in } \\
\text { providing a meaningful } \\
\text { care environment }\end{array}$ \\
\hline $\begin{array}{l}\text { Onieva-Zafra et } \mathrm{al}^{31} \text { / } \\
\text { January } 2018 / \text { Spain }\end{array}$ & $\begin{array}{l}\text { Investigate the effect } \\
\text { of an 8-week nursing } \\
\text { intervention using } \\
\text { reminiscence therapy } \\
\text { and reality orientation } \\
\text { to determine if there } \\
\text { would be a positive } \\
\text { effect on anxiety } \\
\text { and depression } \\
\text { for patients with } \\
\text { dementia }\end{array}$ & $\begin{array}{l}19 \text { participants with } \\
\text { a diagnosis of } A D \text {, } \\
\text { aged }>65 \text { years, and } \\
\text { able to communicate in } \\
\text { a nursing home }\end{array}$ & $\begin{array}{l}\text { Quasi- } \\
\text { experimental, } \\
\text { nonrandomized } \\
\text { controlled, } \\
\text { interrupted time } \\
\text { series }\end{array}$ & $\begin{array}{l}\text { Questionnaires; state } \\
\text { examination; pre-test } \\
\text { and post-intervention } \\
\text { tests }\end{array}$ & $\begin{array}{l}\text { Depression symptoms } \\
\text { can be reduced in } \\
\text { patients with AD after } \\
\text { a twice-weekly, 8-week } \\
\text { music intervention } \\
\text { program }\end{array}$ \\
\hline $\begin{array}{l}\text { Raglio et } \mathrm{al}^{32} / 2015 / \\
\text { Italy }\end{array}$ & $\begin{array}{l}\text { Assess the effects of } \\
\text { active music therapy } \\
\text { and individualized } \\
\text { listening to music } \\
\text { on behavioral } \\
\text { and psychological } \\
\text { symptoms of } \\
\text { dementia }\end{array}$ & $\begin{array}{l}\text { I } 20 \text { participants with } \\
\text { moderate to severe } \\
\text { dementia were randomly } \\
\text { selected for I of } \\
3 \text { treatments }\end{array}$ & $\begin{array}{l}\text { Non-randomized } \\
\text { controlled }\end{array}$ & $\begin{array}{l}\text { Cornell Scale for } \\
\text { Depression, Cornell- } \\
\text { Brown Scale for QOL } \\
\text { and Music Therapy } \\
\text { checklist before and after } \\
\text { treatment and after a } \\
\text { follow-up period }\end{array}$ & $\begin{array}{l}\text { The addition of music } \\
\text { therapy and listening } \\
\text { to music did not show } \\
\text { positive improvement in } \\
\text { patients with dementia, } \\
\text { although it did have } \\
\text { a very small effect on } \\
\text { communication and } \\
\text { relationships }\end{array}$ \\
\hline $\begin{array}{l}\text { Ray et } \mathrm{al}^{34 /} \\
\text { November 2017/ } \\
\text { USA }\end{array}$ & $\begin{array}{l}\text { Describe music } \\
\text { assisted care of } \\
\text { people with dementia } \\
\text { for caregivers, which } \\
\text { will lessen agitation } \\
\text { and anxiety especially } \\
\text { during bathing }\end{array}$ & $\begin{array}{l}\text { I participant with } \\
\text { dementia who has a } \\
\text { history of anxiety and } \\
\text { agitation when bathing } \\
\text { over a period of } 30-60 \\
\text { minutes }\end{array}$ & $\begin{array}{l}\text { Quasi- } \\
\text { experimental }\end{array}$ & $\begin{array}{l}\text { Direct observation by } \\
\text { care givers that had } \\
\text { worked with participant } \\
\text { prior to the intervention } \\
\text { with music }\end{array}$ & $\begin{array}{l}\text { Music-assisted bathing } \\
\text { can lessen the aggressive } \\
\text { and agitated behaviors } \\
\text { during and just prior to } \\
\text { bathing in people with } \\
\text { dementia }\end{array}$ \\
\hline
\end{tabular}

(Continued) 
Table I (Continued)

\begin{tabular}{|c|c|c|c|c|c|}
\hline $\begin{array}{l}\text { Author/date/ } \\
\text { location }\end{array}$ & Aim & Sample/settings & Methods & Assessment tool & Key findings \\
\hline $\begin{array}{l}\text { Ray et } \mathrm{al}^{34} / 2017 / \mathrm{NY} \text {, } \\
\text { USA }\end{array}$ & $\begin{array}{l}\text { Evaluate whether } \\
\text { the effects of music } \\
\text { therapy influence } \\
\text { the symptoms of } \\
\text { depression, agitation, } \\
\text { and wandering for } \\
\text { patients with severe } \\
\text { dementia }\end{array}$ & $\begin{array}{l}\text { I32 participants with } \\
\text { moderate to severe } \\
\text { dementia in } 3 \text { nursing } \\
\text { homes in Brooklyn, } \\
\text { New York }\end{array}$ & $\begin{array}{l}\text { Quasi- } \\
\text { experimental, } \\
\text { nonrandomized } \\
\text { controlled, } \\
\text { interrupted time } \\
\text { series }\end{array}$ & $\begin{array}{l}\text { Cornell Scale of } \\
\text { Depression, the Algase } \\
\text { Wandering Scale, and } \\
\text { the Cohen Mansfield } \\
\text { Agitation Inventory }\end{array}$ & $\begin{array}{l}\text { Depression and agitation } \\
\text { symptoms decreased, } \\
\text { and the symptom of } \\
\text { wandering showed no } \\
\text { change for sessions } \\
\text { three times a week over } \\
2 \text { weeks }\end{array}$ \\
\hline $\begin{array}{l}\text { Ridder et } \mathrm{a}^{35} / 2013 / \\
\text { Europe }\end{array}$ & $\begin{array}{l}\text { Examine the } \\
\text { effect of individual } \\
\text { music therapy on } \\
\text { agitation in people } \\
\text { with dementia } \\
\text { living in nursing } \\
\text { homes and to see } \\
\text { the effect of music } \\
\text { on psychotropic } \\
\text { medication and QOL }\end{array}$ & $\begin{array}{l}42 \text { participants with } \\
\text { dementia in } 14 \text { nursing } \\
\text { homes in Denmark and } \\
\text { Norway }\end{array}$ & $\begin{array}{l}\text { Exploratory, } \\
\text { randomized } \\
\text { controlled, } \\
\text { crossover }\end{array}$ & $\begin{array}{l}\text { Skilled nursing facility } \\
\text { reported data; pre-test } \\
\text { and post-intervention } \\
\text { tests }\end{array}$ & $\begin{array}{l}\text { Six weeks of music } \\
\text { therapy prevents } \\
\text { medication increases } \\
\text { and reduces agitation } \\
\text { disruptiveness in people } \\
\text { with dementia }\end{array}$ \\
\hline $\begin{array}{l}\text { Solé et al }{ }^{36 / 2014 /} \\
\text { Spain }\end{array}$ & $\begin{array}{l}\text { Evaluate the effect of } \\
\text { group music therapy } \\
\text { on QOL of people } \\
\text { with dementia in a } \\
\text { nursing home and } \\
\text { identify and analyze } \\
\text { changes based on } \\
\text { participation }\end{array}$ & $\begin{array}{l}\text { I6 participants with } \\
\text { dementia in a nursing } \\
\text { home in Spain }\end{array}$ & $\begin{array}{l}\text { Exploratory, } \\
\text { nonrandomized } \\
\text { controlled }\end{array}$ & $\begin{array}{l}\text { Direct observation; } \\
\text { pre-test and post- } \\
\text { intervention tests; staff- } \\
\text { reported data }\end{array}$ & $\begin{array}{l}\text { Significant improvement } \\
\text { for emotional well- } \\
\text { being but no significant } \\
\text { difference in QOL. } \\
\text { Interpersonal relations } \\
\text { were worsened and } \\
\text { there was a high level } \\
\text { of participation in the } \\
\text { program }\end{array}$ \\
\hline $\begin{array}{l}\text { Tai et } \mathrm{al}^{37} / \text { June 20I5/ } \\
\text { Taiwan }\end{array}$ & $\begin{array}{l}\text { Identify the effect } \\
\text { of music therapy } \\
\text { on depression and } \\
\text { cognitive function in } \\
\text { residents of senior } \\
\text { citizen apartments }\end{array}$ & $\begin{array}{l}\text { A control group of } \\
19 \text { participants and } \\
\text { intervention group of } \\
41 \text { participants - all } \\
\text { healthy senior apartment } \\
\text { residents aged } \\
\geq 65 \text { years }\end{array}$ & $\begin{array}{l}\text { Experimental, } \\
\text { interrupted time } \\
\text { series }\end{array}$ & $\begin{array}{l}\text { State examination; } \\
\text { pre-test and post- } \\
\text { intervention tests }\end{array}$ & $\begin{array}{l}\text { Music therapy may } \\
\text { postpone cognitive } \\
\text { decline and intense } \\
\text { contact with participants } \\
\text { may improve mood }\end{array}$ \\
\hline $\begin{array}{l}\text { Thomas et al }{ }^{38} / \text { April } \\
2017 / \text { USA }\end{array}$ & $\begin{array}{l}\text { Compare resident } \\
\text { outcomes with the } \\
\text { implementation of an } \\
\text { individualized music } \\
\text { program that was } \\
\text { created to address } \\
\text { psychological and } \\
\text { behavioral symptoms } \\
\text { in patients with } \\
\text { dementia }\end{array}$ & $\begin{array}{l}\text { I2,905 participating } \\
\text { facilities and I } 2,8 \mathrm{II} \\
\text { comparison facilities } \\
\text { across the USA who } \\
\text { implemented the Music } \\
\text { and Memory program }\end{array}$ & Retrospective & $\begin{array}{l}\text { Minimum data set } \\
\text { information }\end{array}$ & $\begin{array}{l}\text { The individualized music } \\
\text { program may result in a } \\
\text { reduction of anxiolytic } \\
\text { medication use and } \\
\text { antipsychotic medication } \\
\text { use, as well as reduce } \\
\text { psychological and } \\
\text { behavioral symptoms }\end{array}$ \\
\hline $\begin{array}{l}\text { Verrusio et al }{ }^{39} / \text { June } \\
2014 / \text { taly }\end{array}$ & $\begin{array}{l}\text { Evaluate the impact } \\
\text { of music therapy } \\
\text { and physical training } \\
\text { in participants with } \\
\text { depression }\end{array}$ & $\begin{array}{l}\text { A control group of } \\
12 \text { participants and an } \\
\text { intervention group of } \\
12 \text { participants }\end{array}$ & $\begin{array}{l}\text { Randomized } \\
\text { controlled }\end{array}$ & $\begin{array}{l}\text { Pre-test and post } \\
\text { intervention tests; } \\
\text { medical record data }\end{array}$ & $\begin{array}{l}\text { In the exercise/music } \\
\text { therapy group, there } \\
\text { was a reduction in } \\
\text { anxiety and depression }\end{array}$ \\
\hline $\begin{array}{l}\text { Werner et a }{ }^{40 /} \\
\text { September } 2015 / \\
\text { Germany }\end{array}$ & $\begin{array}{l}\text { Examine the effect } \\
\text { of interactive group } \\
\text { music therapy vs } \\
\text { recreational group } \\
\text { singing on depressive } \\
\text { symptoms in nursing } \\
\text { home patients }\end{array}$ & $\begin{array}{l}117 \text { residents in } 2 \\
\text { German nursing homes }\end{array}$ & $\begin{array}{l}\text { Two-armed } \\
\text { randomized } \\
\text { controlled, } \\
\text { cluster design }\end{array}$ & $\begin{array}{l}\text { Direct observation; } \\
\text { pre-test and post- } \\
\text { intervention tests }\end{array}$ & $\begin{array}{l}\text { Music therapy decreases } \\
\text { depressive symptoms } \\
\text { more effectively than } \\
\text { recreational signing }\end{array}$ \\
\hline
\end{tabular}

Abbreviations: AD, Alzheimer's disease; GDS, Geriatric Depression Scale; QOL, quality of life; MM, music with movement; MMSE, Mini-Mental State Examination. 
scores, high Geriatric Depression Scale scores, mild to severe dementia, and Alzheimer's disease.

\section{Assessment tools}

A summary of all 30 articles utilized in the qualitative analysis is found in Table 1 . The authors carefully examined the 30 articles and detailed outcomes for residents in nursing homes using music therapy. Each factor was then sorted into positive facilitators or negative barriers and themes were assigned to each point (Table 2). A total of 13 facilitator themes and 11 barrier themes were identified.

\section{Discussion}

Elderly people living in long-term care facilities face cognitive and physical health difficulties which can create challenges for caregivers, loved ones, and health care professionals. Incorporating music can be a simple and effective approach for professional caregivers giving them an additional tool in their efforts to reduce anxiety, feelings of isolation, behaviors, physical decline, and reliance on antipsychotic medications. All stakeholders can benefit from a calmer and more supportive social environment where caregivers may regain valuable time otherwise lost to behavior

Table 2 Positive outcomes for residents in nursing homes using music

\begin{tabular}{|c|c|c|c|c|}
\hline Author & Facilitator & Theme & Barrier & Theme \\
\hline $\begin{array}{l}\text { Altan Sarikaya and } \\
\text { Oguz }\end{array}$ & $\begin{array}{l}\text { Passive music therapy } \\
\text { helped elderly people } \\
\text { increase sleep quality }\end{array}$ & Improved sleep hygiene & $\begin{array}{l}\text { Passive music therapy } \\
\text { cannot be isolated alone } \\
\text { as that which increased } \\
\text { sleep quality }\end{array}$ & $\begin{array}{l}\text { Cannot isolate effects } \\
\text { of music }\end{array}$ \\
\hline Cheung et $\mathrm{al}^{13}$ & $\begin{array}{l}\text { Music interventions are } \\
\text { thought to be useful in } \\
\text { reduction of anxiety based } \\
\text { on Progressively Lowered } \\
\text { Stress Threshold Model }\end{array}$ & Reduced anxiety or stress & $\begin{array}{l}\text { The postulation of } \\
\text { reduction of anxiety and } \\
\text { depressive symptoms can } \\
\text { improve cognition was } \\
\text { not confirmed through } \\
\text { analysis }\end{array}$ & $\begin{array}{l}\text { Difficult to measure } \\
\text { changes in memory and } \\
\text { cognition }\end{array}$ \\
\hline Clements-Cortes $^{14}$ & $\begin{array}{l}\text { Singing in the choir } \\
\text { facilitated by a music } \\
\text { therapist and accompanist } \\
\text { was a beneficial } \\
\text { intervention for improving } \\
\text { mood, happiness, and } \\
\text { energy }\end{array}$ & Positive mood changes & $\begin{array}{l}\text { Extenuating factors that } \\
\text { may have caused anxiety } \\
\text { and rather than show the } \\
\text { music therapy was being } \\
\text { effective in producing } \\
\text { positive results }\end{array}$ & $\begin{array}{l}\text { Cannot isolate effects } \\
\text { of music }\end{array}$ \\
\hline \multirow[t]{2}{*}{ Davidson et al ${ }^{15}$} & $\begin{array}{l}\text { A singing program } \\
\text { can provide positive } \\
\text { social, musical, } \\
\text { physical, and emotional } \\
\text { experiences }\end{array}$ & Improved QOL or well-being & $\begin{array}{l}\text { Singing programs are } \\
\text { dependent on satisfactory } \\
\text { financial support }\end{array}$ & Cost prohibitive \\
\hline & $\begin{array}{l}\text { The singing program } \\
\text { highlighted the social } \\
\text { elements such as isolated } \\
\text { residents participating in } \\
\text { the activity }\end{array}$ & $\begin{array}{l}\text { Increased socialization or } \\
\text { communication }\end{array}$ & & \\
\hline \multirow[t]{3}{*}{ Davison et al ${ }^{16}$} & $\begin{array}{l}\text { Memory boxes (visual with } \\
\text { music accompanying video) } \\
\text { are recommended for } \\
\text { residents with dementia }\end{array}$ & Improved cognition & $\begin{array}{l}\text { It is unsure if residents } \\
\text { heard memory box for } \\
\text { the duration played } \\
\text { because they could leave } \\
\text { their room }\end{array}$ & Difficult to implement \\
\hline & $\begin{array}{l}\text { This study showed positive } \\
\text { effects for adults with } \\
\text { dementia by reducing } \\
\text { agitation }\end{array}$ & Dementia/Alzheimer's care & $\begin{array}{l}\text { It is expensive to produce } \\
\text { the memory box }\end{array}$ & Cost prohibitive \\
\hline & $\begin{array}{l}\text { Materials from the distant } \\
\text { past provide pleasure and } \\
\text { provide positive exchanges } \\
\text { both with family and staff } \\
\text { members }\end{array}$ & $\begin{array}{l}\text { Increased socialization or } \\
\text { communication }\end{array}$ & & \\
\hline
\end{tabular}

(Continued) 
Table 2 (Continued)

\begin{tabular}{|c|c|c|c|c|}
\hline Author & Facilitator & Theme & Barrier & Theme \\
\hline \multirow[t]{2}{*}{$E_{d w a r d s}{ }^{17}$} & $\begin{array}{l}\text { Music Mirrors toolkit } \\
\text { is utilized to speak to } \\
\text { individuals with dementia }\end{array}$ & $\begin{array}{l}\text { Increased socialization or } \\
\text { communication }\end{array}$ & $\begin{array}{l}\text { Music is embedded in } \\
\text { narratives }\end{array}$ & $\begin{array}{l}\text { Cannot isolate effects } \\
\text { of music }\end{array}$ \\
\hline & $\begin{array}{l}\text { Music Mirrors toolkit can } \\
\text { be utilized in care plan }\end{array}$ & Personalized care plan & & \\
\hline Eggert et $\mathrm{al}^{18}$ & $\begin{array}{l}\text { Approaches with nature } \\
\text { images and music used on } \\
A D \text { or other dementias led } \\
\text { to increased engagement } \\
\text { and reduced disordered } \\
\text { behaviors }\end{array}$ & $\begin{array}{l}\text { Reduced agitation or behavior } \\
\text { problems }\end{array}$ & $\begin{array}{l}\text { Half of the participants in } \\
\text { music therapy in addition } \\
\text { to the study approaches }\end{array}$ & $\begin{array}{l}\text { Cannot isolate effects } \\
\text { of music }\end{array}$ \\
\hline \multirow[t]{3}{*}{ Fu et $\mathrm{al}^{4}$} & $\begin{array}{l}\text { Participants had improved } \\
\text { cognition following } \\
\text { I2-week group singing } \\
\text { sessions }\end{array}$ & Improved cognition & $\begin{array}{l}\text { Singing sessions did not } \\
\text { necessarily improve sleep } \\
\text { quality, sleep duration, } \\
\text { sleep efficacy, and sleep } \\
\text { disorder }\end{array}$ & $\begin{array}{l}\text { QOL or well-being not } \\
\text { significantly improved }\end{array}$ \\
\hline & $\begin{array}{l}\text { Participants reported } \\
\text { increased respiratory } \\
\text { strength and health }\end{array}$ & Improved physical health & & \\
\hline & $\begin{array}{l}\text { Participants had increased } \\
\text { socialization during and } \\
\text { after group sessions }\end{array}$ & $\begin{array}{l}\text { Increased socialization or } \\
\text { communication }\end{array}$ & & \\
\hline Gill and Englert ${ }^{19}$ & $\begin{array}{l}\text { Autonomic responses } \\
\text { were in sync with melody } \\
\text { and music }\end{array}$ & Improved physical health & $\begin{array}{l}\text { There are reasons to } \\
\text { believe that falls are } \\
\text { somewhat seasonal, } \\
\text { and music might have } \\
\text { an impact with further } \\
\text { research }\end{array}$ & $\begin{array}{l}\text { Showed aspects of } \\
\text { physical health decline }\end{array}$ \\
\hline \multirow[t]{3}{*}{ Gök Ugur et al ${ }^{20}$} & $\begin{array}{l}\text { Music decreased the } \\
\text { symptoms of depression }\end{array}$ & Reduced depression & $\begin{array}{l}\text { Music did not have any } \\
\text { effect on ventilator } \\
\text { residents' heart rate or } \\
\text { blood pressure }\end{array}$ & $\begin{array}{l}\text { Showed aspects of } \\
\text { physical health decline }\end{array}$ \\
\hline & $\begin{array}{l}\text { The study also found that } \\
\text { music lowered blood } \\
\text { pressure and heart rate }\end{array}$ & Improved physical health & & \\
\hline & $\begin{array}{l}\text { Participants reported an } \\
\text { increase in self-confidence } \\
\text { and coping mechanisms }\end{array}$ & $\begin{array}{l}\text { Reduced agitation or behavior } \\
\text { problems }\end{array}$ & & \\
\hline Gopi and Preetha ${ }^{21}$ & $\begin{array}{l}\text { Music decreased } \\
\text { depression }\end{array}$ & Reduced depression & $\begin{array}{l}\text { Participants excluded } \\
\text { those who are being } \\
\text { treated for mental health } \\
\text { issues, and those who } \\
\text { have a chronic medical } \\
\text { condition }\end{array}$ & $\begin{array}{l}\text { Applies to specific } \\
\text { population only }\end{array}$ \\
\hline \multirow[t]{2}{*}{ Hamilton et $\mathrm{al}^{22}$} & $\begin{array}{l}\text { QOL was improved with } \\
\text { spirituality }\end{array}$ & Improved QOL or well-being & $\begin{array}{l}\text { Participants were } \\
\text { already from religious } \\
\text { organizations and already } \\
\text { well socialized within } \\
\text { religious or spiritual groups }\end{array}$ & $\begin{array}{l}\text { Applies to specific } \\
\text { population only }\end{array}$ \\
\hline & $\begin{array}{l}\text { There was a decrease in } \\
\text { mental health issues when } \\
\text { religious music was part of } \\
\text { one's life }\end{array}$ & Increased spirituality & & \\
\hline
\end{tabular}


Table 2 (Continued)

\begin{tabular}{|c|c|c|c|c|}
\hline Author & Facilitator & Theme & Barrier & Theme \\
\hline & $\begin{array}{l}\text { Religious music helped } \\
\text { lessen the effect of } \\
\text { stressful life events }\end{array}$ & Reduced anxiety or stress & & \\
\hline \multirow[t]{5}{*}{ Johnson et $\mathrm{al}^{23}$} & $\begin{array}{l}\text { The participants reported } \\
\text { a higher QOL of those } \\
\text { that participated in the } \\
\text { group singing sessions }\end{array}$ & Improved QOL or well-being & $\begin{array}{l}\text { The researchers found } \\
\text { that } \mathrm{QOL} \text { decreased with } \\
\text { age, regardless of group } \\
\text { singing sessions }\end{array}$ & $\begin{array}{l}\text { Cannot isolate effects } \\
\text { of music }\end{array}$ \\
\hline & $\begin{array}{l}\text { There was a decrease in } \\
\text { physiological functions } \\
\text { within those in group } \\
\text { singing sessions }\end{array}$ & Improved physical health & & \\
\hline & $\begin{array}{l}\text { Participants were living } \\
\text { in a culture where choral } \\
\text { singing is popular }\end{array}$ & $\begin{array}{l}\text { Increased socialization or } \\
\text { communication }\end{array}$ & & \\
\hline & $\begin{array}{l}\text { The study found that the } \\
\text { participants had improved } \\
\text { socialization following } \\
\text { sessions }\end{array}$ & $\begin{array}{l}\text { Increased socialization or } \\
\text { communication }\end{array}$ & & \\
\hline & $\begin{array}{l}\text { Participants reported a } \\
\text { decrease in symptoms of } \\
\text { depression and isolation }\end{array}$ & Reduced depression & & \\
\hline \multirow[t]{2}{*}{ Kerer et $\mathrm{al}^{24}$} & $\begin{array}{l}\text { There was a decrease in } \\
\text { physiological functions, } \\
\text { such as lower heart rate } \\
\text { and blood pressure, while } \\
\text { listening to music }\end{array}$ & Improved physical health & $\begin{array}{l}\text { It is difficult to measure } \\
\text { memory function in those } \\
\text { with } A D\end{array}$ & $\begin{array}{l}\text { Difficult to measure } \\
\text { changes in memory and } \\
\text { cognition }\end{array}$ \\
\hline & $\begin{array}{l}\text { There was reported } \\
\text { increase in memory } \\
\text { performance in the test } \\
\text { group }\end{array}$ & Improved cognition & & \\
\hline \multirow[t]{2}{*}{ Kirkland et $\mathrm{al}^{25}$} & $\begin{array}{l}\text { Music made dementia } \\
\text { residents feel socially } \\
\text { connected }\end{array}$ & $\begin{array}{l}\text { Increased socialization or } \\
\text { communication }\end{array}$ & $\begin{array}{l}\text { This study did not give } \\
\text { participants with dementia } \\
\text { time to build rapport with } \\
\text { the researchers }\end{array}$ & Decreased socialization \\
\hline & $\begin{array}{l}\text { The music caused } \\
\text { dementia residents to feel } \\
\text { a spiritual connection to a } \\
\text { higher power }\end{array}$ & Increased spirituality & & \\
\hline \multirow[t]{2}{*}{ Lancioni et $\mathrm{al}^{26}$} & $\begin{array}{l}\text { There was positive } \\
\text { participation when music, } \\
\text { and specifically favorite } \\
\text { songs, were played }\end{array}$ & $\begin{array}{l}\text { Increased socialization or } \\
\text { communication }\end{array}$ & $\begin{array}{l}\text { Participants were unable } \\
\text { to utilize the ability to self- } \\
\text { regulate the use of music } \\
\text { when made available }\end{array}$ & $\begin{array}{l}\text { QOL or well-being not } \\
\text { significantly improved }\end{array}$ \\
\hline & & & $\begin{array}{l}\text { There was no improvement } \\
\text { in participation when } \\
\text { Alzheimer's participants } \\
\text { had the ability to control } \\
\text { when they listened to } \\
\text { music }\end{array}$ & $\begin{array}{l}\text { QOL or well-being not } \\
\text { significantly improved }\end{array}$ \\
\hline Liao et $\mathrm{al}^{27}$ & $\begin{array}{l}\text { The depressive symptoms } \\
\text { among community } \\
\text { dwellers were suppressed } \\
\text { with the combination of } \\
\text { music and Tai Chi }\end{array}$ & Reduced depression & $\begin{array}{l}\text { The benefit of Tai Chi } \\
\text { remains controversial. } \\
\text { Those differences may be } \\
\text { attributed to population } \\
\text { characteristics }\end{array}$ & $\begin{array}{l}\text { Applies to specific } \\
\text { population only }\end{array}$ \\
\hline
\end{tabular}

(Continued) 
Table 2 (Continued)

\begin{tabular}{|c|c|c|c|c|}
\hline Author & Facilitator & Theme & Barrier & Theme \\
\hline & $\begin{array}{l}\text { The limbic system is } \\
\text { positively affected by } \\
\text { musical pitch and rhythm }\end{array}$ & Improved physical health & & \\
\hline \multirow[t]{3}{*}{ Liu et $\mathrm{al}^{28}$} & $\begin{array}{l}\text { Music provides spiritual } \\
\text { support for patients and } \\
\text { family }\end{array}$ & Increased spirituality & $\begin{array}{l}\text { Treatment plans need to } \\
\text { be tailored to patients } \\
\text { with different primary } \\
\text { diagnoses, referral } \\
\text { reasons, and personal } \\
\text { characteristics. Decisions } \\
\text { regarding music therapy } \\
\text { should be made by both } \\
\text { the family and the patient }\end{array}$ & Difficult to implement \\
\hline & $\begin{array}{l}\text { Emotional and spiritual } \\
\text { support is the number } \\
\text { one reason patients who } \\
\text { choose hospice services }\end{array}$ & Increased spirituality & $\begin{array}{l}\text { Data could not determine } \\
\text { if music therapy is both } \\
\text { cost effective or time } \\
\text { prohibitive }\end{array}$ & Cost prohibitive \\
\hline & & & $\begin{array}{l}\text { After a 6-week follow up, } \\
\text { patients regressed slightly } \\
\text { back to pretreatment } \\
\text { results }\end{array}$ & $\begin{array}{l}\text { Positive improvements } \\
\text { were only temporary }\end{array}$ \\
\hline \multirow[t]{8}{*}{ Matto et $\mathrm{al}^{29}$} & $\begin{array}{l}\text { This study showed a } \\
\text { statistically significant } \\
\text { reduction in depression }\end{array}$ & Reduced depression & $\begin{array}{l}\text { Initially some participants } \\
\text { hesitated to participate, } \\
\text { or they did not add to the } \\
\text { conversation as the words } \\
\text { did not come out }\end{array}$ & Decreased socialization \\
\hline & $\begin{array}{l}\text { Patients showed a slight } \\
\text { increase in cognitive } \\
\text { scores }\end{array}$ & Improved cognition & & \\
\hline & $\begin{array}{l}\text { Patients enjoyed } \\
\text { remembering, recognizing, } \\
\text { and expressing what they } \\
\text { were feeling when listening } \\
\text { to music }\end{array}$ & Positive mood changes & & \\
\hline & $\begin{array}{l}\text { Patients felt more } \\
\text { supportive and expressive }\end{array}$ & Positive mood changes & & \\
\hline & $\begin{array}{l}\text { Patients learned about } \\
\text { other peers and felt } \\
\text { more connected with the } \\
\text { community }\end{array}$ & $\begin{array}{l}\text { Increased socialization or } \\
\text { communication }\end{array}$ & & \\
\hline & $\begin{array}{l}\text { Individuals had a reduction } \\
\text { in agitation }\end{array}$ & $\begin{array}{l}\text { Reduced agitation or behavior } \\
\text { problems }\end{array}$ & & \\
\hline & $\begin{array}{l}\text { Music helps a person } \\
\text { organize external sensory } \\
\text { stimuli in familiar ways, } \\
\text { as opposed to being } \\
\text { overwhelmed with } \\
\text { unfamiliar external sensory } \\
\text { stimuli }\end{array}$ & Improved cognition & & \\
\hline & $\begin{array}{l}\text { Relationships within group } \\
\text { activities can reduce pain, } \\
\text { improve mood and well- } \\
\text { being }\end{array}$ & Improved QOL or well-being & & \\
\hline
\end{tabular}

(Continued) 
Table 2 (Continued)

\begin{tabular}{|c|c|c|c|c|}
\hline Author & Facilitator & Theme & Barrier & Theme \\
\hline Melhuish et $\mathrm{al}^{30}$ & $\begin{array}{l}\text { Music can help the staff } \\
\text { understand the residents' } \\
\text { emotional experience and } \\
\text { develop more positive and } \\
\text { interactive relationships } \\
\text { with them }\end{array}$ & $\begin{array}{l}\text { Increased socialization or } \\
\text { communication }\end{array}$ & $\begin{array}{l}\text { It was hard to coordinate } \\
\text { staff participants with } \\
\text { changing schedules }\end{array}$ & Difficult to implement \\
\hline \multirow[t]{3}{*}{ Onieva-Zafra et $\mathrm{al}^{31}$} & $\begin{array}{l}\text { Reduction of depression } \\
\text { symptoms in patients } \\
\text { through } 2 \text { interventions } \\
\text { per week }\end{array}$ & Reduced depression & $\begin{array}{l}\text { There were no significant } \\
\text { changes in symptoms of } \\
\text { anxiety }\end{array}$ & $\begin{array}{l}\text { No difference or an } \\
\text { increase in anxiety or } \\
\text { agitation }\end{array}$ \\
\hline & $\begin{array}{l}\text { Easy to implement by } \\
\text { a typical nursing team } \\
\text { working in a nursing home } \\
\text { (once the relevant skills } \\
\text { and knowledge to conduct } \\
\text { music, reminiscence } \\
\text { therapy, and reality } \\
\text { orientation are acquired). } \\
\text { The nurse should be the } \\
\text { principal contact in music } \\
\text { therapy }\end{array}$ & Personalized care plan & & \\
\hline & $\begin{array}{l}\text { Depressive symptoms } \\
\text { were lessened in patients } \\
\text { with } A D\end{array}$ & Dementia/Alzheimer's care & & \\
\hline \multirow[t]{2}{*}{ Raglio et $\mathrm{a}^{32}$} & $\begin{array}{l}\text { The increase in } \\
\text { communicative musical } \\
\text { behaviors may be related } \\
\text { to changes in emotional } \\
\text { involvement during the } \\
\text { music therapy sessions }\end{array}$ & $\begin{array}{l}\text { Increased socialization or } \\
\text { communication }\end{array}$ & $\begin{array}{l}\text { No significant differences } \\
\text { were observed between } \\
\text { persons with dementia } \\
\text { who were treated with } \\
\text { music therapy in addition } \\
\text { to standard care }\end{array}$ & $\begin{array}{l}\text { QOL or well-being not } \\
\text { significantly improved }\end{array}$ \\
\hline & $\begin{array}{l}\text { The goal of music } \\
\text { therapy is to bridge } \\
\text { the communication gap } \\
\text { between staff and persons } \\
\text { with dementia }\end{array}$ & $\begin{array}{l}\text { Increased socialization or } \\
\text { communication }\end{array}$ & & \\
\hline \multirow[t]{3}{*}{$\begin{array}{l}\text { Ray and Fitzsimmons }{ }^{33} \\
\text { (first article) }\end{array}$} & $\begin{array}{l}\text { Music-assisted bathing } \\
\text { made shower times easier } \\
\text { for people with dementia }\end{array}$ & Positive mood changes & $\begin{array}{l}\text { The wrong kinds of } \\
\text { music or volume can } \\
\text { have adverse effects on } \\
\text { participants }\end{array}$ & $\begin{array}{l}\text { Negative emotions } \\
\text { from music could occur }\end{array}$ \\
\hline & $\begin{array}{l}\text { Research shows that it is } \\
\text { important to pay attention } \\
\text { to verbal and nonverbal } \\
\text { responses to music, } \\
\text { adjusting where necessary }\end{array}$ & $\begin{array}{l}\text { Increased socialization or } \\
\text { communication }\end{array}$ & & \\
\hline & $\begin{array}{l}\text { Music-assisted care may } \\
\text { address neuropsychiatric } \\
\text { symptoms of dementia } \\
\text { by reducing agitation and } \\
\text { improving mood }\end{array}$ & $\begin{array}{l}\text { Increased socialization or } \\
\text { communication }\end{array}$ & & \\
\hline $\begin{array}{l}\text { Ray and Mittelman }{ }^{34} \\
\text { (second article) }\end{array}$ & $\begin{array}{l}\text { Interventions reduced } \\
\text { systems of depression and } \\
\text { agitation }\end{array}$ & $\begin{array}{l}\text { Reduced agitation or behavior } \\
\text { problems }\end{array}$ & $\begin{array}{l}\text { Music did not reduce the } \\
\text { symptom of wandering }\end{array}$ & $\begin{array}{l}\text { QOL or well-being not } \\
\text { significantly improved }\end{array}$ \\
\hline
\end{tabular}

(Continued) 
Table 2 (Continued)

\begin{tabular}{|c|c|c|c|c|}
\hline \multirow[t]{5}{*}{ Author } & Facilitator & Theme & Barrier & Theme \\
\hline & $\begin{array}{l}\text { Effects of music therapy } \\
\text { reduced the symptoms of } \\
\text { dementia better than the } \\
\text { effects of medication }\end{array}$ & Improved physical health & $\begin{array}{l}\text { I month after } \\
\text { the intervention, } \\
\text { improvements began } \\
\text { to dwindle }\end{array}$ & $\begin{array}{l}\text { Positive improvements } \\
\text { were only temporary }\end{array}$ \\
\hline & $\begin{array}{l}\text { Rhythm and physically } \\
\text { based music programs } \\
\text { significantly affected } \\
\text { behaviors impacted by } \\
\text { dementia }\end{array}$ & Positive mood changes & & \\
\hline & $\begin{array}{l}\text { Participation in music } \\
\text { therapy and gentle } \\
\text { movements can decrease } \\
\text { neuropsychiatric behaviors } \\
\text { considered to be negative }\end{array}$ & $\begin{array}{l}\text { Reduced agitation or behavior } \\
\text { problems }\end{array}$ & & \\
\hline & $\begin{array}{l}\text { Effects of music therapy } \\
\text { can affect symptoms in as } \\
\text { little as } 2 \text { weeks }\end{array}$ & Positive mood changes & & \\
\hline \multirow[t]{4}{*}{ Ridder et $\mathrm{al}^{35}$} & $\begin{array}{l}\text { Music therapy reduces } \\
\text { agitation disruptiveness in } \\
\text { persons with dementia }\end{array}$ & $\begin{array}{l}\text { Reduced agitation or behavior } \\
\text { problems }\end{array}$ & $\begin{array}{l}\text { Music therapy requires } \\
\text { interdisciplinary } \\
\text { collaboration to be } \\
\text { successful }\end{array}$ & Difficult to implement \\
\hline & $\begin{array}{l}\text { Music therapy prevented } \\
\text { psychotropic medication } \\
\text { increases }\end{array}$ & Reduced medicine intervention & $\begin{array}{l}\text { Decreases in the } \\
\text { frequency of agitated } \\
\text { behavior were non- } \\
\text { significant when music } \\
\text { therapy was used }\end{array}$ & $\begin{array}{l}\text { No difference or an } \\
\text { increase in anxiety or } \\
\text { agitation }\end{array}$ \\
\hline & $\begin{array}{l}\text { The music therapy was } \\
\text { person-centered and } \\
\text { catered to the participant's } \\
\text { interests }\end{array}$ & Personalized care plan & & \\
\hline & $\begin{array}{l}\text { Music therapy helped } \\
\text { prevent caregiver burnout } \\
\text { and stress }\end{array}$ & Reduced anxiety or stress & & \\
\hline Solé et $\mathrm{al}^{36}$ & $\begin{array}{l}\text { Music therapy showed } \\
\text { significant improvement } \\
\text { for emotional well-being }\end{array}$ & Improved QOL or well-being & $\begin{array}{l}\text { Participants experienced } \\
\text { a significant worsening for } \\
\text { interpersonal relations }\end{array}$ & Decreased socialization \\
\hline \multirow[t]{2}{*}{ Tai et $\mathrm{al}^{37}$} & $\begin{array}{l}\text { Music intervention may } \\
\text { postpone cognitive decline }\end{array}$ & Improved cognition & & \\
\hline & $\begin{array}{l}\text { Intense contact with other } \\
\text { people seemed to improve } \\
\text { the mood status of the } \\
\text { participants }\end{array}$ & $\begin{array}{l}\text { Increased socialization or } \\
\text { communication }\end{array}$ & & \\
\hline \multirow[t]{3}{*}{ Thomas et $\mathrm{al}^{38}$} & $\begin{array}{l}\text { Individualized music } \\
\text { program (music and } \\
\text { memory) reduces } \\
\text { in antipsychotic and } \\
\text { anxiolytic medication use }\end{array}$ & Reduced medicine intervention & $\begin{array}{l}\text { No differences were } \\
\text { observed in symptoms } \\
\text { of depression using the } \\
\text { individualized music } \\
\text { program }\end{array}$ & $\begin{array}{l}\text { No difference or an } \\
\text { increase in depression }\end{array}$ \\
\hline & $\begin{array}{l}\text { Reductions in behavioral } \\
\text { disturbance presence and } \\
\text { frequency associated with } \\
\text { dementia }\end{array}$ & $\begin{array}{l}\text { Reduced agitation or behavior } \\
\text { problems }\end{array}$ & $\begin{array}{l}\text { There are extra costs for } \\
\text { implementing the program } \\
\text { including iPod and music } \\
\text { purchases and staff } \\
\text { training }\end{array}$ & Cost prohibitive \\
\hline & $\begin{array}{l}\text { The music program was } \\
\text { effective for dementia } \\
\text { participants }\end{array}$ & Dementia/Alzheimer's care & & \\
\hline
\end{tabular}


Table 2 (Continued)

\begin{tabular}{|c|c|c|c|c|}
\hline Author & Facilitator & Theme & Barrier & Theme \\
\hline \multirow[t]{3}{*}{ Verrusio et $\mathrm{al}^{39}$} & $\begin{array}{l}\text { Exercise and music } \\
\text { therapy reduces symptoms } \\
\text { of depression }\end{array}$ & Reduced depression & $\begin{array}{l}\text { Music therapy may need } \\
\text { exercise to be most } \\
\text { effective }\end{array}$ & $\begin{array}{l}\text { Cannot isolate effects } \\
\text { of music }\end{array}$ \\
\hline & $\begin{array}{l}\text { Exercise and music therapy } \\
\text { reduces the symptoms of } \\
\text { anxiety }\end{array}$ & Reduced anxiety or stress & & \\
\hline & $\begin{array}{l}\text { Music genres were chosen } \\
\text { based on participant } \\
\text { interest which was } \\
\text { beneficial }\end{array}$ & Personalized care plan & & \\
\hline \multirow[t]{3}{*}{ Werner et $\mathrm{al}^{40}$} & $\begin{array}{l}\text { Depressive symptoms } \\
\text { improved when } \\
\text { participants were assigned } \\
\text { to music therapy ( } 6 \text { weeks, } \\
12 \text { weeks) }\end{array}$ & Reduced depression & $\begin{array}{l}\text { Recreational singing } \\
\text { increased symptoms of } \\
\text { depression }\end{array}$ & $\begin{array}{l}\text { No difference or an } \\
\text { increase in depression }\end{array}$ \\
\hline & $\begin{array}{l}\text { Music therapy was } \\
\text { effective in patients with } \\
\text { and without dementia }\end{array}$ & Dementia/Alzheimer's care & & \\
\hline & $\begin{array}{l}\text { Music therapy attends } \\
\text { to basic needs and } \\
\text { resource-oriented } \\
\text { development by focusing } \\
\text { on social competences and } \\
\text { individual competences } \\
\text { like creativity }\end{array}$ & Personalized care plan & & \\
\hline
\end{tabular}

Abbreviations: AD, Alzheimer's disease; QOL, quality of life.

management actions and other behavior issues. A review of the literature found that music positively impacts physical and mental health factors.

Thirteen facilitator themes were identified that occurred 66 total times within the review of the literature. Their description, occurrence, sum, and frequency percentages are shown in Table 3. The most common facilitator for the impact of music on physical and mental health factors was increased socialization or communication in $18.18 \%$ of articles reviewed. ${ }^{4,15-17,23,25,26,29,30,32,33,37}$ The importance of socialization and communication was described as intense contact with other people, which seemed to improve the mood status of participants. ${ }^{37}$ Participants were shown to have increased socialization before and after group singing sessions. ${ }^{4}$ The introduction of music and reminiscent memories provided positive exchanges between participants, family members, and staff members ${ }^{16}$ and the use of music caused residents with dementia in a nursing home feel socially connected. ${ }^{25}$

Other articles suggest that music improved physical

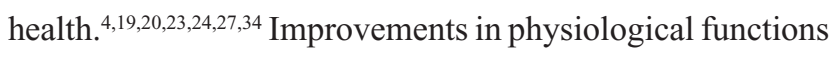
such as decreases in heart rate and blood pressure, coupled with improved respiratory rates, were a few of the recurring themes within the discussion of physical health..$^{19,20,23,24}$
Reduced depression was a theme in $12.12 \%$ of the articles..$^{20,21,23,27,29,31,39,40}$ Two separate studies utilized preand post-test results of depressive symptoms and found that reported depressive symptoms significantly improved following the implementation of music., ${ }^{4,29}$ Actively utilizing music as an approach to behavior management of depressive symptoms can be useful in the nursing facility setting. ${ }^{21,23}$

Researchers found that music reduced agitation and behavior problems in residents with dementia, Alzheimer's, or mild cognitive deficits. ${ }^{18,20,29,34,35,38}$ Two studies demonstrated the positive effects of providing agitated long-term care residents a therapeutic outlet, such as music and singing with implications for health care professionals to consider nonpharmacological treatments. ${ }^{34,35}$

Another facilitator was improved cognition. . $, 16,24,29,37^{2}$ Mini-Mental State Examination (MMSE) scores improved after the music, imagery, and movement treatment intervention in one study was implemented in a long-term care facility for persons with a dementia diagnosis. ${ }^{29}$ Also, MMSE pre- and post-test scores showed improved cognition ${ }^{29}$ and music use may even postpone cognitive decline in the therapeutic-music experimental group vs the MMSE scores of the control group..$^{37}$ 
Table 3 Facilitator themes associated with positive outcomes using music in nursing homes

\begin{tabular}{|l|l|l|l|}
\hline Facilitator themes & Occurrences & Sum & $\%$ \\
\hline Increased socialization or communication & $4,15,16,17,23,25,26,29,30,32,33,37$ & 12 & 18.18 \\
\hline Improved physical health & $4,19,20,23,24,27,34$ & 7 & 10.61 \\
\hline Reduced depression & $20,21,23,27,29,31,39,40$ & 8 & 12.12 \\
\hline Reduced agitation or behavior problems & $18,20,29,34,35,38$ & 6 & 9.09 \\
\hline Improved cognition & $4,16,24,29,37$ & 5 & 7.58 \\
\hline Improved quality of life or well-being & $15,22,23,29,36$ & 5 & 7.58 \\
\hline Personalized care plan & $17,31,35,39,40$ & 5 & 7.58 \\
\hline Reduced anxiety or stress & $13,22,35,39$ & 4 & 6.06 \\
\hline Dementia/Alzheimer's care & $16,31,38,40$ & 4 & 6.06 \\
\hline Positive mood changes & $14,29,33,34$ & 4 & 6.06 \\
\hline Increased spirituality & $22,25,28$ & 3 & 4.55 \\
\hline Reduced medicine intervention & 35,38 & 2 & 1 \\
\hline Improved sleep hygiene & 12 & 66 & 3.03 \\
\hline Total & & & 1.52 \\
\hline
\end{tabular}

Other facilitators suggest that music improved participants' QOL or well-being. ${ }^{15,22,23,29,36}$ One study evaluated the effect of singing programs developed specifically for older adults and discovered that these programs had a positive impact upon the well-being and QOL of the participants. The group singing program facilitated a new sort of experience that participants reported looking forward to. ${ }^{15}$

Evidence also showed that utilizing personalized care plans as behavioral interventions in nursing facilities was effective. ${ }^{17,31,35,39,40}$ This is significant for long-term care facilities that utilize an interdisciplinary approach to nonpharmacological-based interventions to behavior management.

A reduction in anxiety or stress occurred in $6.06 \%$ of studies reviewed. ${ }^{13,22,35,39}$ Results found that the music therapy group reported positive effects and a reduction on their overall level of anxiety over a 6-month time frame vs the group that began pharmacological interventions for their anxiety and did not participate in a music therapy group. ${ }^{39}$ Caregivers are at risk of burnout when behaviors in a clinical setting are not managed, and when it feels as though all interventions have been put in place. Utilizing music as an intervention has shown to decrease not only the anxiety and stress of the residents but also the overall anxiety and stress level of those caring for them. ${ }^{35}$ The Minimum Data Set was used to evaluate these changes in symptoms of anxiety and stress. Music was found to have overall significant positive changes for caregivers when caring for those with dementia and Alzheimer's due to the decrease in behaviors, anxiety, stress, and stimulation. . $^{16,31,38,40}$

Music use was also associated with positive mood changes. ${ }^{14,29,33,34}$ Both participants with cognitive impairments and those without were found to have more positivity, reported happiness, increased energy, and a feeling of connectedness with others when involved in a choir directed by a music therapist. ${ }^{14}$ Patients enjoy remembering, recognizing, and expressing the feelings associated with music and they found a way to be more expressive toward caregivers and loved ones. ${ }^{29}$ Whereas some studies discovered that music takes time to improve mood, one found that music can positively affect mood and behaviors in as little as 2 weeks. ${ }^{33}$

Music and spirituality have long been associated with each other and a couple of studies explored the connection. ${ }^{22,25,28}$ One study suggests that spirituality transcends the biological and psycho-social, which is especially important for those with dementia in that dementia threatens one's personhood and loss of self. ${ }^{25}$ The incorporation of religious songs into spiritual care interventions may allow someone living in a community to feel connected not only to a higher power but also to those participating in the spiritual music rituals as well. ${ }^{22}$

Listening to or participating in singing and music has positive physical and mental outcomes in that there was a reduction in the use of antipsychotics and anxiolytic medications..$^{35,38}$ This is especially important for nursing facilities not only to manage the overall health and well-being of their residents but also to follow regulatory guidelines showing strict adherence to psychotropic dose reductions and interventions for behavior management. One study found a decrease in usage of both anxiolytic and antipsychotics following the implementation of music and memory programs, offering a low-cost non-pharmacological solution to a growing trend in the USA. ${ }^{38}$ 
Passively listening to music at bedtime may improve sleep hygiene in those with severe memory problems. Significant improvements within the group that listened to music while trying to fall asleep and that they were found to have better sleep quality, duration, and efficiency. ${ }^{12}$

Eleven barrier themes were identified regarding the effect that music has on mental and physical health as shown in Table 4. A review of the literature identified that $25.71 \%$ of studies found that the most prevalent issue surrounding this topic was that research cannot isolate the effects of music. ${ }^{12,14,17,18,21-23,27,39}$ Research barriers found that extenuating circumstances may mitigate the results found in studies such as sleep quality due to existing sleep patterns or clinical issues. ${ }^{17}$ Stimulation outside of music intervention may have caused more anxiety for those in a nursing facility and these residents may find themselves over-stimulated by instruction. ${ }^{18}$ One study excluded participants with mental health issues or a chronic medical condition. Excluded groups could have been utilized to determine further if physical and/or mental health could be improved through interventions, however they were not included. ${ }^{21}$ One study gathered participants from a religious organization who were already well socialized and well connected. ${ }^{23}$

Music intervention was found to be cost prohibitive in some cases. ${ }^{15,16,28,37}$ Costs accrued may be equipment such as iPods and required staff training, ${ }^{37}$ or digital Music Memory Boxes. ${ }^{16}$ Data were not available as to whether hiring a music therapist was cost effective in the long run. ${ }^{28}$

Another barrier to implementing music is that the program may be difficult to implement. ${ }^{16,28,30,35}$ Two studies suggested that music therapy requires interdisciplinary collaboration to be successful, ${ }^{35}$ which is difficult due to shifting staff schedules. ${ }^{16}$ Also, decisions need to be made with the clinical team, the resident, and their representative which takes organization, time, and follow through..$^{28}$

QOL and well-being were not significantly improved when music intervention was implemented in $11.43 \%$ of the studies. ${ }^{4,26,32,34}$ Pre- and post-test interviews did not find that QOL was improved following a 12-week group singing program. ${ }^{4}$ No significant differences were observed in one study exploring therapeutic music activities in addition to standard nursing home care of persons with dementia. ${ }^{32}$ Wandering residents were not affected by music, and their QOL and well-being did not change in an observational study that implemented music and iPod therapy. ${ }^{34}$

Three studies demonstrated that music decreased socialization. ${ }^{25,29,36}$ Participants with cognitive deficits were not given enough time to build rapport with the researchers ${ }^{25}$ or the participants were unable to communicate their thoughts and feelings. ${ }^{29}$ One study found that participants with cognitive impairments experienced significant worsening of interpersonal relations due to the stimulation and stress or music and physical movement. ${ }^{36}$

Another barrier to determine the physical and mental health benefits of music is the difficulty in measuring changes in memory and cognition in a sample of participants who have deficits in memory and cognition. ${ }^{13,24}$ It is very difficult to measure self-reported changes in cognition when one is already cognitively impaired with a dementia or Alzheimer's diagnosis. Studies put excessive demands on subjects' memory and ability to verbalize their thoughts and feelings. ${ }^{24}$

Two different studies show that there was no difference or an increase in anxiety or agitation ${ }^{31,35}$ or that there was no difference or an increase in depression. ${ }^{38,40}$ An increase in depression was found in one study utilizing recreational group singing because participants had trouble following

Table 4 Barrier themes associated with negative or null outcomes using music in nursing homes

\begin{tabular}{|c|c|c|c|}
\hline Barrier themes & Occurrences & Sum & $\%$ \\
\hline Cannot isolate effects of music & $12,14,17,18,21,22,23,27,39$ & 9 & 25.71 \\
\hline Cost prohibitive & $15,16,28,37$ & 4 & 11.43 \\
\hline Difficult to implement & $16,28,30,35$ & 4 & 11.43 \\
\hline Quality of life or well-being not significantly improved & $4,26,32,34$ & 4 & 11.43 \\
\hline Decreased socialization & $25,29,36$ & 3 & 8.57 \\
\hline Difficult to measure changes in memory and cognition & 13,24 & 2 & 5.71 \\
\hline No difference or an increase in anxiety or agitation & 31,35 & 2 & 5.71 \\
\hline No difference or an increase in depression & 38,40 & 2 & 5.71 \\
\hline Positive improvements were only temporary & 28,34 & 2 & 5.71 \\
\hline Showed aspects of physical health decline & 19,20 & 2 & 5.71 \\
\hline Negative emotions from music could occur & 33 & 1 & 2.86 \\
\hline Total & & 35 & \\
\hline
\end{tabular}


along with the instructions either due to existing physical or mental impairments, which led to feelings of frustration and hopelessness. ${ }^{35}$

Positive improvements of physical and mental health due to music were found to be temporary. ${ }^{28,34}$ One study found that the benefits of music dwindled a month after the initial implementation, ${ }^{34}$ and the other study found that 6 weeks following the study yielding positive results, residents were found to have regressed to pre-test levels of physical and mental health. ${ }^{28}$

Another barrier to utilizing music is that some studies showed aspects of physical health decline. ${ }^{19,20}$ More falls happened during and after music were played in those with dementia, which researchers felt was attributed to sensory overload. ${ }^{19}$ One study suggests that music and singing increased heart rate and respiration for those participating in group singing exercises. ${ }^{20}$ The wrong type of music or volume showed that negative emotions from music could occur. ${ }^{33}$

\section{Limitations}

This review had a limitation in that the term music was open to interpretation of the reviewers and researchers alike. The date range for the article search criteria allowed the reviewers to go back 5 years, which examined older adults in that timeframe. The articles identified different age groups as elder adults, making it difficult to identify whom exactly is considered the older adult age. This is seemingly interpreted differently by different researchers.

\section{Conclusion}

The results of the recent research on the relationship between music and positive mental and physical health outcomes are significant. The positive effects include improved mood, cognition, physical health, QOL and well-being, spirituality, sleep, increased socialization, and communication. There is also evidence of reduced depression, anxiety, stress, agitation and behavior problems, as well as fewer medical interventions. Music has an integral part in elder care and studies continue to show its relevance.

Analysis of music used in nursing facilities has several positive outcomes including but not limited to reduced depression, reduced agitation, improved cognition, improved QOL and well-being, and positive mood changes. Most articles noted that larger samples and/or additional studies would need to be conducted to help correctly identify and pinpoint the aspects that are beneficial to the nursing facility residents. The barriers and limitation identified are not necessarily negative aspects of the review but also include areas that need to be evaluated and augmented for future studies. The data collected in this review support that incorporating music improves the QOL in the elder population; therefore, music should be a component of elder care in nursing facilities.

\section{Author contributions}

All authors contributed toward data analysis, drafting and revising the paper, gave final approval of the version to be published, and agree to be accountable for all aspects of the work.

\section{Disclosure}

The authors report no conflicts of interest in this work.

\section{References}

1. United States Census Bureau. Older people projected to outnumber children for first time in U.S. history [press release] (2018 Mar 13) [cited Jul 29, 2018]. Available from: https://www.census.gov/newsroom/ press-releases/2018/cb18-41-population-projections.html. Accessed July 29, 2018.

2. Harris-Kojetin L, Sengupta M, Park-Lee E. Long-term care providers and services users in the United States: data from the national study of long-term care providers, 2013-2014. National Center for Health Statistics. Vital Health Stat. 2016;3(38):x-xii; 1-105.

3. Department of Health and Human Services, Office of the Assistant Secretary for Planning and Evaluation. The Future Supply of Longterm Care Workers in Relation to the Aging Baby Boom Generation: Report to Congress [Internet]. Washington (DC): HHS; 2003 May 14 [cited Jul 29, 2018]. Available from: http://aspe.hhs.gov/daltcp/reports/ ltcwork.htm. Accessed July 29, 2018.

4. Fu MC, Belza B, Nguyen $\mathrm{H}$, et al. Impact of group-singing on older adult health in senior living communities: a pilot study. Arch Gerontol Geriatr. 2018;76:138-146.

5. Waltman E. Music therapy. Nursing \& Allied Health Resources Section (NAHRS) Newsletter [serial on the Internet]. 2018 Apr;38(2):5-7.

6. Gutgsell KJ, Schluchter M, Margevicius S, et al. Music therapy reduces pain in palliative care patients: a randomized controlled trial. $J$ Pain Symptom Manage. 2013;45(5):822-831.

7. Burns DS, Perkins SM, Tong Y, Hilliard RE, Cripe LD. Music therapy is associated with family perception of more spiritual support and decreased breathing problems in cancer patients receiving hospice care. J Pain Symptom Manage. 2015;50(2):225-231.

8. Bergdahl E, Allard P, Gustafson Y. Depression among the very old with dementia. Int Psychogeriatr. 2011;23(5):756-763.

9. Dev A, Smitha KV, Pillai RR. Music therapy for institutionalised elderly persons with depression. Dysphrenia. 2015;6(1):15-19.

10. Spiro N. Music and dementia: observing effects and searching for underlying theories. Aging Ment Health. 2010;14(8):891-899.

11. Quach J, Lee JA. Do music therapies reduce depressive symptoms and improve QOL in older adults with chronic disease? Nursing. 2017;47(6):58-63.

12. Altan Sarikaya N, Oguz S. Effect of passive music therapy on sleep quality in elderly nursing home residents. J Psychiatr Nurs. 2016;7(2): $55-60$.

13. Cheung DSK, Lai CKY, Wong FKY, Leung MCP. The effects of the music-with-movement intervention on the cognitive functions of people with moderate dementia: a randomized controlled trial. Aging Ment Health. 2018;22(3):306-315.

14. Clements-Cortes A. Buddy's glee club two: choral singing benefits for older adults. Can J Music Ther. 2014;20(1):85-109. 
15. Davidson JW, McNamara B, Rosenwax L, Lange A, Jenkins S, Lewin G. Evaluating the potential of group singing to enhance the well-being of older people. Australas J Ageing. 2014;33(2):99-104.

16. Davison TE, Nayer K, Coxon S, et al. A personalized multimedia device to treat agitated behavior and improve mood in people with dementia: a pilot study. Geriatr Nurs. 2016;37(1):25-29.

17. Edwards H. Music mirrors: a resource for communication and reminiscence. Nurs Resid Care. 2015;17(5):274-276.

18. Eggert J, Dye CJ, Vincent E, et al. Effects of viewing a preferred nature image and hearing preferred music on engagement, agitation, and mental status in persons with dementia. SAGE Open Med. 2015;3(3):205031211560257.

19. Gill LM, Englert NC. A music intervention's effect on falls in a dementia unit. J Nurse Pract. 2013;9(9):562-567.

20. Gök Ugur H, Yaman Aktaş Y, Orak OS, Saglambilen O, Aydin Avci İ. The effect of music therapy on depression and physiological parameters in elderly people living in a Turkish nursing home: a randomizedcontrolled trial. Aging Ment Health. 2017;21(12):1280-1286.

21. Gopi D, Preetha AK. Effectiveness of music therapy on depressive symptoms among elderly in selected geriatric homes. Int J Nurs Educ. 2016;8(3):163-166.

22. Hamilton JB, Sandelowski M, Moore AD, Agarwal M, Koenig HG. "You need a song to bring you through": the use of religious songs to manage stressful life events. Gerontologist. 2013;53(1):26-38.

23. Johnson JK, Louhivuori J, Stewart AL, et al. Quality of life (QOL) of older adult community choral singers in Finland. Int Psychogeriatr. 2013;25(7):1055-1064.

24. Kerer M, Marksteiner J, Hinterhuber H, et al. Explicit (semantic) memory for music in patients with mild cognitive impairment and early-stage Alzheimer's disease. Exp Aging Res. 2013;39(5):536-564.

25. Kirkland K, Fortuna MC, Kelson E, et al. Music therapy and spiritual care for persons with dementia: A mixed-methods study. Can J Music Ther. 2014;20(1):10-37.

26. Lancioni GE, Singh NN, O'Reilly MF, et al. Self-regulated music stimulation for persons with Alzheimer's disease: impact assessment and social validation. Dev Neurorehabil. 2013;16(1):17-26.

27. Liao SJ, Tan MP, Chong MC, Chua YP. The impact of combined music and tai chi on depressive symptoms among community-dwelling older persons: a cluster randomized controlled trial. Issues Ment Health Nurs 2018;39(5):398-402.

28. Liu X, Burns DS, Hilliard RE, Stump TE, Unroe KT. Music therapy clinical practice in hospice: differences between home and nursing home delivery. J Music Theory. 2015;52(3):376-393.
29. Matto HC, Tompkins CJ, Ihara ES, Inoue M, Byrd A. Results from a music, imagery, and movement treatment intervention in a long-term care facility. Fam Soc. 2015;96(4):277-283.

30. Melhuish R, Beuzeboc C, Guzmán A. Developing relationships between care staff and people with dementia through music therapy and dance movement therapy: a preliminary phenomenological study. Dementia. 2017;16(3):282-296.

31. Onieva-Zafra MD, Hernández-Garcia L, Gonzalez-del-Valle MT, Parra-Fernández ML, Fernandez-Martinez E. Music intervention with reminiscence therapy and reality orientation for elderly people with Alzheimer disease living in a nursing home: a pilot study. Holist Nurs Pract. 2018;32(1):43-50.

32. Raglio A, Bellandi D, Baiardi P, et al. Effect of active music therapy and individualized listening to music on dementia: a multicenter randomized controlled trial. J Am Geriatr Soc. 2015;63(8):1534-1539.

33. Ray KD, Fitzsimmons S. Music-assisted bathing: making shower time easier for people with dementia. J Gerontol Nurs. 2014;40(2):9-13.

34. Ray KD, Mittelman MS. Music therapy: a nonpharmacological approach to the care of agitation and depressive symptoms for nursing home residents with dementia. Dementia. 2017;16(6):689-710.

35. Ridder HM, Stige B, Qvale LG, Gold C. Individual music therapy for agitation in dementia: an exploratory randomized controlled trial. Aging Ment Health. 2013;17(6):667-678.

36. Solé C, Mercadal-Brotons M, Galati A, De Castro M. Effects of group music therapy on quality of life, affect, and participation in people with varying levels of dementia. J Music Ther. 2014;51(1):103-125.

37. Tai SY, Wang LC, Yang YH. Effect of music intervention on the cognitive and depression status of senior apartment residents in Taiwan. Neuropsychiatr Dis Treat. 2015;11:1449-1454

38. Thomas KS, Baier R, Kosar C, Ogarek J, Trepman A, Mor V. Individualized music program is associated with improved outcomes for U.S. nursing home residents with dementia. Am J Geriatr Psychiatry. 2017;25(9):931-938.

39. Verrusio W, Andreozzi P, Marigliano B, et al. Exercise training and music therapy in elderly with depressive syndrome: a pilot study. Complement Ther Med. 2014;22(4):614-620.

40. Werner J, Wosch T, Gold C. Effectiveness of group music therapy versus recreational group singing for depressive symptoms of elderly nursing home residents: pragmatic trial. Aging Ment Health. 2017;21(2) $147-155$.
Clinical Interventions in Aging

\section{Publish your work in this journal}

Clinical Interventions in Aging is an international, peer-reviewed journal focusing on evidence-based reports on the value or lack thereof of treatments intended to prevent or delay the onset of maladaptive correlates of aging in human beings. This journal is indexed on PubMed Central, MedLine,

\section{Dovepress}

CAS, Scopus and the Elsevier Bibliographic databases. The manuscript management system is completely online and includes a very quick and fair peer-review system, which is all easy to use. Visit http://www.dovepress. com/testimonials.php to read real quotes from published authors. 